\title{
Free Will Skepticism and Its Implications: An Argument for Optimism \\ Gregg D. Caruso
}

Free will skepticism maintains that what we do and the way we are is ultimately the result of factors beyond our control and because of this we are never morally responsible for our actions in the basic desert sense the sense that would make us truly deserving of blame and praise, punishment and reward. In recent years, a number of contemporary philosophers have advanced and defended versions of free will skepticism or skepticism about moral responsibility, including Derk Pereboom (2001, 2014), Galen Strawson (1986/2010, 1994), Neil Levy (2011), Bruce Waller (201 I, 201 5), and myself (Caruso 2012 ). Critics, however, often complain that adopting the skeptical perspective would have dire consequences for our interpersonal relationships, society, morality, meaning, and the law. They fear, for instance, that relinquishing belief in free will and basic desert moral responsibility would leave us unable to adequately deal with criminal behavior, increase antisocial conduct, and undermine meaning in life.

In response, free will skeptics argue that life without free will and basic desert moral responsibility would not be as destructive as many people believe. According to optimistic skeptics, prospects of finding meaning in life or of sustaining good interpersonal relationships, for instance, would not be threatened (see Pereboom 200I, 20I4; Waller 20II; Caruso 20I7b; Pereboom and Caruso 2018). And although retributivism and severe punishment, such as the death penalty, would be ruled out, incapacitation and rehabilitation programs would still be justified (see, e.g., Pereboom 200I, 2014; Vilhauer 2010, 2013; Levy 2012; Corrado 2013; Caruso 2016, 2017a, 2019a; and Pereboom and Caruso 2018).

Who then is correct? What would the actual consequences of embracing free will skepticism be? In this chapter I will argue that belief in free will and basic desert moral responsibility, rather than being a good thing, actually has a dark side and that we would be better off without it. 
My position is therefore one of optimistic skepticism and disillusionism. ${ }^{\mathrm{I}}$ I maintain that belief in free will, rather than providing the pragmatic benefits many claim, is too often used to justify treating people in severe and demeaning ways. The problem, I maintain, is the belief that individuals justly deserve what they get. The idea of just deserts - which is central to the moral responsibility system (see Waller 20II, 20I3) - is a pernicious one. For one, it often encourages punitive excess in criminal justice, including extreme forms of retributive punishment such as the death penalty. It is also used to perpetuate social and economic inequalities. The simple fact is that what we do and the way we are is ultimately the result of factors beyond our control - whether those be determinism, chance, or luck (see Pereboom 200I, 20I4; Levy 20II; Caruso 20I2, $2018,2019 \mathrm{~b})$. We are not, as the moral responsibility system would like us to believe, purely or ultimately self-made men and women.

In the following, I will take free will to mean the control in action required for an agent to be morally responsible in the basic desert sense the sense needed to justify certain kinds of desert-based judgments, attitudes, or treatments, such as resentment, indignation, moral anger, backward-looking blame, and retributive punishment (see Pereboom 200I, 20I4; Caruso and Morris 2017) - and I will focus on the putative pragmatic benefits of believing in free will and basic desert moral responsibility, rather than arguing for free will skepticism directly. This is because, regardless of the philosophical debate over free will, a profound pragmatic question remains: would the consequences of giving up the belief in free will cause nihilism and despair as some maintain, or would it rather have a humanizing effect on our practices and policies, freeing us from the negative effects of free will belief? If it turns out that belief in free will, rather than being a good thing, actually has a dark side, then this would help remove one of the major obstacles in the way of accepting free will skepticism - e.g., concerns over its negative consequences. It would also support disillusionism over illusionism as the proper course of action for free will skeptics.

In Section 3.I, I begin by discussing two common concerns people have with relinquishing the belief in free will and argue that both are unfounded. In Section 3.2, I then make the case for the dark side of free

\footnotetext{
See the opening chapter of this volume for a comprehensive summary of optimistic skepticism and disillusionism and how they differ from, say, the illusionism of Saul Smilansky (2000, 2013). Other skeptics who are optimistic about the implications of life without free will and/or basic desert moral responsibility include Pereboom (200I, 20I3a, b, 20I4), Waller (20I I, 20I3, 20I4b), Levy (20II), and Milam (2016). For a defense of disillusionism, see Nadelhoffer (201 I).
} 
will by discussing recent findings in moral and political psychology that reveal interesting, and potentially troubling, correlations between people's free will beliefs and their other moral, religious, and political beliefs. I conclude in section 3.3 by outlining my nonretributive alternative for addressing criminal behavior, the public health-quarantine model. My comments will be aimed at showing that, contra critics, we should be optimistic about the practical implications of adopting the skeptical perspective and abandoning belief in free will and basic desert moral responsibility.

\section{I Addressing Pragmatic Concerns with Free Will Skepticism}

Let me begin with the concern that giving up free will belief will increase antisocial behavior. This concern has been fueled largely by two widely reported-on studies in social psychology (Vohs and Schooler 2008; Baumeister et al. 2009). Kathleen Vohs and Jonathan Schooler (2008) found, for example, that participants who were exposed to anti-free will primes were more likely to cheat than participants exposed to pro-free will or neutral primes. In one study, they asked 30 college students to solve math problems on a computer. The volunteers were told that, owing to a computer glitch, the answers would pop up on the screen after the problem if they did not hit the space bar. They were asked to do so but told that no one would know either way. In addition, some of the participants in the study were first asked to read passages by well-respected scientists to the effect that we do not have free will. In particular, they read one of two passages from The Astonishing Hypothesis, a book written by Francis Crick (1994), the Nobel Prize-winning scientist. The participants read statements claiming that rational, high-minded people - including most scientists, according to Crick - now recognize that free will is an illusion. Vohs and Schooler found that students exposed to the anti-free will primes were more likely to cheat than those in the control group. Additional findings by Baumeister et al. (2009) found that participants who are exposed to anti-free will primes behave more aggressively than participants exposed to pro-free will or neutral primes. ${ }^{2}$

\footnotetext{
2 These two studies are often cited as empirical support for the claim that stronger free will beliefs are negatively associated with increased antisocial behavior. Additional studies have purported to find that stronger free will beliefs are positively associated with helpfulness, gratitude, job performance, and making amends for one's transgressions (see Baumeister et al. 2009; MacKenzie, Vohs, and Baumeister 20I 4; Stillman et al. 20IO; Stillman and Baumeister 20I0). I will focus here primarily on the former claim, but much of what I will argue also applies to these later studies.
} 
While these findings appear to support concerns over the antisocial consequences of relinquishing free will belief, I advise caution in drawing any universal or sweeping conclusions from them. There are powerful criticisms of the methodology of these studies, which place into doubt the supposed connection between disbelief in free will and any long-term increase in antisocial behavior. First of all, the passages used to prime disbelief in free will appear to be priming the wrong thing. Several critics have noted that instead of priming belief in hard determinism or hard incompatibilism (see Pereboom 200I, 20I4; Pereboom and Caruso 2018), the Crick excerpt subjects read is actually priming a scientific reductionist view of the mind, one that is proclaimed to demonstrate that free will is an illusion. Free will skepticism, however, need not entail such a reductionist view and the priming passages may be giving participants the mistaken impression that scientists have concluded that their beliefs, desires, and choice are causally inefficacious - a claim not embraced by most philosophical skeptics. ${ }^{3}$

Furthermore, subsequent studies have had a difficult time replicating these findings and they have been involved in the so-called replication scandal in social psychology (see Zwaan 2013; Carey and Roston 2015; Open Science Collaboration 20 I 5). The New York Times, for example, ran a story focusing on the failure to replicate the findings of Vohs and Schooler since it was the most cited of the roo studies included the Reproducibility Project (Carey and Roston 20 I 5; Open Science Collaboration 2015). And even before the Reproducibility Project was unable to replicate the findings, Rolf Zwaan (2013) at the University of Rotterdam had similar difficulties. In the original Vohs and Schooler study, subjects in the anti-free will condition reported weaker free will beliefs than subjects in the control condition. In contrast, Zwaan found no differences between

3 This criticism has been made by Eddy Nahmias on the Garden of Forking Paths Blog (http://gfp .typepad.com/the_garden_of_forking_pat/2008/oI/on-the-benefits.html) and others. It's important to be careful not to misrepresent or caricature the claims of the skeptic. Free will skeptics do not deny that we make choices or engage in acts of deliberation and reasoning. Rather, they hold that these acts themselves are the result of factors ultimately beyond the control of the agent (see, e.g., Pereboom 200I, 2014). It's important therefore that Vohs and Schooler prime the correct belief and not the mistaken impression that scientific findings have obviated the possibility of local control (Clark 2013). As Thomas Clark has noted, "if people come to believe they don't have ultimate control, and if they have something like the authors' (mis) conception of what not having it entails, then indeed they might become demoralized. This could explain the results of the study. But it's important to see what's demoralizing isn't the empirically and logically well-supported conclusion that we don't have contra-causal, libertarian free will, that we are not ultimately self-created, but the inference that if we are not free in this way then we aren't causally efficacious agents" (Clark 2013). 
the anti-free will condition and the control condition. He was also unable to replicate the effect on cheating - i.e., he found no difference in cheating behavior between the anti-free will condition and the control condition. One possible explanation is that the original experiment was done with only 30 subjects, whereas Zwaan used I 50 subjects. Another possible explanation has to do with the nature of the anti-free will prime Vohs and Schooler used. Eddy Nahmias, in describing his difficulties in trying to replicate the findings, writes: "the effects don't always replicate and they only seem to work with the over-the-top primes that suggest all kinds of threats to agency." He goes on to say, "no one has shown that telling people they lack just what philosophical (not scientific!) skeptics say they lack and nothing more has any bad effects on behavior or sense of meaning." 4

Additional support for Nahmias's claim can be found in studies conducted by Nadelhoffer and Wright (2018) and Crone and Levy (2018). Crone and Levy (2018), for instance, conducted four studies originally concerned with identifying possible mediators and/or moderators of the reported positive association between free will beliefs and various desirable moral characteristics (e.g., greater helpfulness, less dishonesty). In their attempt to further study these correlations, however, they unexpectedly found no association between free will beliefs and moral behavior. They go on to conclude that there is currently no reason to think free will believers are nicer people or that diminishing free will beliefs will increase antisocial behavior. Nadelhoffer and Wright (2018) point to additional problems with the kinds of vignette-based primes used in the literature on prosocial/ antisocial effects of belief in free will. In their studies, they used three different primes specially designed to manipulate people's beliefs about free will. In each case, they found that the primes failed to move participant's beliefs. They write:

In this respect, our work should serve as a cautionary tale for philosophers, psychologists, and pundits who want to discuss the potential ramifications of the supposed death of free will. For while it's certainly possible for people to change their minds about free will, it's not clear that researchers have figured out effective, reliable, and stable methods for bringing these epistemic changes about (even temporarily). (Nadelhoffer and Wright 2018: 272)

\footnotetext{
${ }^{4}$ Eddy Nahmias made these comments on the blog Flickers of Freedom on 3/18/2015: http:// philosophycommons.typepad.com/flickers_of_freedom/201 5/03/free-will-skepticism-just-world-beliefand-punitiveness/comments/page/I/\#comments.
} 
After their initial primes failed to have the effects they intended, they decided to try the prime used by Vohs and Schooler since, in their words, "As far as anti-free will primes go, this is bludgeon" (Nadelhoffer and Wright 2018: 288). Here people did show a decrease in free will beliefs, but (as pointed out earlier) the problem with this prime is that "[i]t not only challenges free will but it also challenges dualism, the soul, selfawareness, and even choice itself" (Nadelhoffer and Wright 2018: 288).

Setting aside these replication and priming concerns for a moment, there is a third concern and it has to do with the relevance of these findings to disbelief in free will. Assuming for the moment that the findings are real and can be replicated, there are alternative explanations for the cheating behavior that have nothing to do with belief in free will, per se. It is equally plausible that the cheating behavior is being driven by the more general fact that participants are being told that one of their cherished beliefs has been shown to be an illusion by science. On this alternative, the cheating behavior would have less to do with disbelief in free will and more to do with ego depletion more generally. That is, perhaps people are simply more likely to cheat after reading passages from scientific authorities challenging (or even mocking) their cherished beliefs because it depletes their self-control, which in turn weakens the ability to trump the self-interested baseline desire to cheat. ${ }^{5}$ It would be rather easy, in fact, to test this alternative. One could, for example, challenge participants (say) pro-American beliefs by having them read extended quotes from a famous authority (say, Noam Chomsky) that challenge or mock the beliefs, then checking to see whether this increases their propensity to cheat. If it does, this would support the alternative explanation presented earlier since it would suggest that the results in the Vohs and Schooler studies are not being driven by anything unique about belief in free will. Until this alternative is tested and ruled out, Vohs and Schooler's findings remain in doubt.

Lastly, these antisocial consequences come immediately following the prime, are limited in scope, and appear only to be temporary. This is very important to keep in mind since, even if we were to set aside the previous two concerns, these studies establish, at best, that participants were temporarily morally compromised after being exposed to anti-free will primes. They say absolutely nothing about the long-term effects of free will skepticism. Once people properly understand what the denial of free will

5 I am grateful to Thomas Nadelhoffer and Eddy Nahmias for bring this objection to my attention on the now-defunct blog The Garden of Forking Paths (January and February 2008). 
entails (and what it does not entail), and once they have sufficiently come to terms with it, there is no reason to think (at least not from these studies) that we would find an overall increase in antisocial behavior.

An illustrative analogy here would be the unfounded concerns voiced in the past about disbelief in God. It was long argued (and, perhaps, is still argued in certain quarters of the United States) that if people were to come to disbelieve in God, the moral fiber of society would disintegrate and we would see a marked increase in antisocial behavior. The reality, however, has turned out to be quite the opposite. Several studies have shown, for example, that murder and violent crime rates are actually higher in highly religious countries than in more secular countries (Fox and Levin 2000; Fajnzylber et al. 2002; Paul 2005; Jensen 2006; Zuckerman 2009). Within the United States, we see the same pattern. Census data, for example, reveal that states with the highest murder rates tend to be the most religious. And these findings are not limited to murder rates, as rates of all violent crime tend to be higher in "religious" states (Ellison et al. 2003; Death Penalty Information Center 2008; Zuckerman 2009). And if one looks beyond crime statistics, one finds similar trends with divorce rates, domestic violence, and intolerance - e.g., studies reveal that atheists and agnostics have lower divorce rates than religious Americans (Barna Research Group Survey I999, 2007), conservative Christian women in Canada experienced higher rates of domestic violence than nonaffiliated women (Brinkerhoff $e t$ al. I992), and nonbelievers are in general less prejudiced, anti-Semitic, racist, dogmatic, ethnocentric, closed-minded, and authoritarian (Altemeyer 2003; Zuckerman 2009). Given how wrong people were about the putative harms of disbelief in God, a healthy dose of skepticism would likewise be warranted here.

Let me now turn to a second concern people have with free will skepticism. Many fear that, by rejecting retributivism and the concept of just deserts, we will lose the ability to protect human dignity and to ensure punishment is proportional. If we give up on retributive punishment entirely, critics question what reason do we have to see to it that punishment is proportional to the harm caused and the type of agent? The worry is that, without basic desert moral responsibility, there will be no limits on the harsh treatment meted out to criminals (and perhaps even innocent people). If especially cruel punishment works, then without the restraints imposed by considerations of just deserts there will be no limits on the harshness of punishment. It's the constraint of just deserts, critics contend, that keeps punishment proportional and allows us to respect the 
dignity and worth of all persons - since it is often argued that even severe punishment, administered because one is a morally responsible autonomous person who justly deserves punishment due to his or her own choices, preserves one's status as a person and a member of the human community of responsible agents (see, e.g., Morris 1968; Lewis I97I; Oldenquist I988).

While concerns over proportionality are important ones, the worry that relinquishing the concept of just deserts will lead to harsh and inhumane treatment of persons is overblown. Free will skeptics have two general ways of responding to this objection. The first is to develop an alternative to retributive punishment that is consistent with free will skepticism and capable of respecting human dignity. The second is to examine the question empirically and ask whether belief in just deserts and retributive justice ensures punishment is proportional any better than the alternatives. I will explore the first option in Section 3.3, where I will argue that the public health-quarantine model is not only an ethically defensible and practically workable alternative to retributive punishment, it is more humane than retributivism and preferable to other nonretributive alternatives. For the moment, then, I will focus on the real-life effects of relinquishing belief in free will and basic desert moral responsibility. The empirical question, I maintain, is an important one, since, if critics are wrong about the protective power of basic desert moral responsibility and the constraints it places on proportional punishment, this concern too loses much of its force.

Empirically speaking, then, does belief in just deserts and retributive justice ensure punishment is proportional? Bruce Waller has done an excellent job examining this question empirically and he sets up the cultural expectations as follows:

Belief in individual moral responsibility is deep and broad in both the United States and England; in fact, the belief seems to be more deeply entrenched in those cultures than anywhere else-certainly deeper there than in Europe. That powerful belief in moral responsibility is not an isolated belief, existing independently of other cultural factors; rather, it is held in place - and in turn, helps anchor-a neo-liberal cultural system of beliefs and values. At the opposite end of the scale are social democratic corporatist cultures like Sweden that have taken significant steps beyond the narrow focus on individual moral responsibility. With that picture in view, consider the basic protections which philosophers have claimed that the moral responsibility system affords: first, protection against extreme punitive measures; second, protection of the dignity and rights of those who are held morally responsible and subject to punishment; and third, a special 
protection of the innocent against unjust punishment. According to the claim that strong belief in individual moral responsibility protects against abuses, we would expect the United States and Great Britain (the neoliberal cultures with the strongest commitment to individual moral responsibility) to score best in providing such protections; and we would predict that Norway, Sweden, and Denmark (the social democratic corporatist cultures, with much more qualified belief in individual moral responsibility) would be the worst abusers. (Waller 20 I 4a: 6; see also 20 I 4b)

When we actually make the comparison, however, we find the exact opposite. That is, in point of fact, the stronger the belief in moral responsibility (as in the United States) the harsher the punishment, the greater the skepticism of moral responsibility (as in Norway) the weaker the inclination toward punishment.

One can see this by examining only a few key statistics. The United States makes up only $5 \%$ of the world's population, yet houses $25 \%$ of the world's prisoners - that's one of the highest rates of incarceration known to mankind. The Unites States imprisons more than 700 prisoners for every I00,000 of population. Compare that to the social democratic countries with a much weaker commitment to individual moral responsibility, such as Sweden and Finland, where the imprisonment rate hovers around 70 per 100,000. In 2012, nearly 7 million US residents were incarcerated, on supervised parole, or on probation. Furthermore, the United States not only imprisons at a much higher rate, it also imprisons in notoriously harsh conditions. For example:

In 2007, the European Court of Human Rights refused to allow the extradition of six men charged in the U.S. with terrorism, on the grounds that their confinement in U.S. supermax prisons would constitute torture and violate basic human rights; along similar lines, Amnesty International (20I2) has concluded that conditions in Arizona's maximum security prisons are a violation of international standards for humane treatment, while a recent study by the New York Bar Association (20II) found that conditions in supermax prisons violated the U.S. Constitutional prohibition against cruel and unusual punishment and also violated international treaty regulations forbidding torture. (Waller 2014a: 8)

American supermax prisons are often cruel places, using a number of harsh forms of punishment, including extended solitary confinement. Prisoners are isolated in windowless, soundproof cubicles for 23 to 24 hours each day, sometimes for decades. Under such conditions, prisoners experience severe suffering, often resulting in serious psychological problems. Supreme court Justice Anthony Kennedy, for instance, recently stated 
that, "solitary confinement literally drives men mad." Looked at empirically, then, it's nigh impossible to defend the claim that commitment to just deserts and retributivism ensures proportional and humane punishment. In fact, the opposite seems to be the case - the problem of disproportionate punishment seems to grow more out of a desire for retribution and the belief that people justly deserve what they get than from free will skepticism. I therefore concur with Waller when he concludes, "it is difficult to escape the conclusion that commitment to moral responsibility exacerbates rather than prevents excessively harsh punitive policies" (Waller 20I 4a: 7).

Recent empirical work in social psychology further indicates that how we assign responsibility is correlated with prior judgments of what counts as being morally bad, which are in turn dependent upon other, larger, social and cultural factors. This is also problematic for those who claim that preserving belief in moral responsibility will keep punishment proportional in any objective sense. Take, for example, psychologist Mark Alicke's culpable control model of blame. It proposes that our desire to blame someone intrudes on our assessments of that person's ability to control his or her thoughts or behavior. As Valerie Hardcastle describes:

Deciding that someone is responsible for an act, which is taken to be the conclusion of a judgment, is actually part of our psychological process of assessing blame. If we start with a spontaneous negative reaction, then that can lead to our hypothesizing that the source of the action is blameworthy as well as to an active desire to blame that source. This desire, in turn, skews our interpretations of the available evidence such that it supports our blame hypothesis. We highlight evidence that indicates negligence, recklessness, impure motives, or a faulty character, and we ignore evidence that suggests otherwise. In other words, instead of dispassionately judging whether someone is responsible, we validate our spontaneous reaction of blameworthiness. (Hardcastle 2018: 320)

In fact, data suggest that we often exaggerate a person's actual or potential control over an event to justify our blame judgment and we will even change the threshold of how much control is required for a blame judgment (Alicke et al. 2008; see also Neimeth and Sosis 1973; Efran 1974; Sosis 1974; Berg and Vidmar 1975; Lerner et al. 1976; Lerner and Miller 1978; Schlenker 1980; Snyder et al. 1983; Alicke 1994, 2008; Lagnado and Channon 2008; Clark et al. 2014; Everett et al., 2018).

${ }^{6}$ He made this statement before the House Appropriations Subcommittee on Financial Services and Federal Government, as reported on in the Huffington Post on 3/24/2015: www.huffington post.com/2015/03/24/anthony-kennedy-solitary-confinement_n_6934550.html. 
A recent set of studies by Cory Clark and her colleagues (Shariff et al. 20I4), for example, found that a key factor promoting belief in free will is a fundamental desire to blame and hold others morally responsible for their wrongful behaviors. Across five studies they found evidence that greater belief in free will is due to heightened punitive motivations. In one study, for instance, an ostensibly real classroom cheating incident led to increased free will beliefs, presumably due to heightened punitive motivations. In a second study, they found that the prevalence of immoral behavior, as measured by crime and homicide rates, predicted free will belief on a country level. These findings suggest that our desire to blame and hold others morally responsible comes first and drives our belief in free will, rather than the other way around.

Other researchers have found that our judgment on whether an action was done on purpose or not is influenced by our moral evaluation of the outcome of certain actions - i.e., whether we morally like or dislike it (Nadelhoffer 2006). Additional findings have found an asymmetric understanding of the moral nature of our own actions and those of others, such that we judge our own actions and motivations as more moral than those of the average person (Epley and Dunning 2000). As Maureen Sie describes:

In cases of other people acting in morally wrong ways we tend to explain those wrongdoings in terms of the agent's lack of virtue or morally bad character traits. We focus on those elements that allow us to blame agents for their moral wrongdoings. On the other hand, in cases where we ourselves act in morally reprehensible ways we tend to focus on exceptional elements of our situation, emphasizing the lack of room to do otherwise. (Sie 2013: 283)

These empirical findings help support the claim that our moral responsibility practices are often driven, possibly primarily driven, by our desire to blame, punish, and strike back at moral transgressors, rather than, and often in lieu of, our more rational and objective judgments about free will, control, and moral responsibility.

\subsection{Unjust Deserts: The Dark Side of Free Will}

Let me now turn to the other side of the coin and argue that disbelief in free will, rather than bringing about negative consequence, could actually bring about good, freeing us from a number of harmful tendencies, beliefs, and practices. While most of the empirical work done thus far has focused 
on the potential upside of believing in free will, there is now a growing body of evidence suggesting that disbelief in free will may have certain positive effects (see, e.g., Pizarro et al. 2003; Monterosso et al. 2005; Aspinwall et al. 2012; Carey and Paulhus 2013; Nadelhoffer and Tocchetto 2013; Shariff et al. 2014; Earp et al. 2018). Recent findings in moral and political psychology, for example, suggest that there may be a potential downside to believing in free will and moral responsibility since there are potentially troubling correlations between people's free will beliefs and their other moral, religious, and political beliefs.

Recent empirical work by Jasmine Carey and Del Paulhus (2013), for example, has found that free will beliefs correlate with increased religiosity, punitiveness, and political conservative beliefs and attitudes such as just world belief (JWB) and right wing authoritarianism (RWA). They found these correlations by administering their Free Will and Determinism Scale known as FAD-Plus (Paulhus and Carey 20 II) - a 27-item scale used to measure people's beliefs and attitudes about free will and related concepts along with measures of religiosity, political conservativism, JWBs, and RWA. It's important here to highlight just how worrisome some of these correlations are. Take, for example, a few of the sample items used to validate belief in a just world.

\section{- Just World Belief Scale (Lerner 1980):}

○ "By and large, people deserve what they get."

- "Although evil men may hold political power for a while, in the general course of history good wins out."

- "People who meet with misfortune have often brought it on themselves."

And here are sample items from the RWA scale:

\section{- The Right Wing Authoritarianism Scale (Altemeyer 1996):}

- "The established authorities generally turn out to be right about things, while the radicals and protestors are usually just 'loud mouths' showing off their ignorance."

- "Our country desperately needs a mighty leader who will do what has to be done to destroy the radical new ways of sinfulness that are ruining us."

- "It is always better to trust the judgment of the proper authorities in government and religion than to listen to the noisy rabblerousers in our society who are trying to create doubt in people's minds." 
These items express troublesome and perhaps even potentially dangerous ideas, as I will try to explain in a moment. Carey and Paulhus also found a relationship between beliefs about free will and punishment - in particular, they found that believing more strongly in free will was correlated with increased punitiveness. They found that free will believers were more likely to call for harsher criminal punishment in a number of hypothetical scenarios. This is unsurprising since, as Thomas Nadelhoffer and Daniela Goya Tocchetto point out: "It makes a priori sense that people who believe more strongly in free will would be more interested in giving wrongdoers their just deserts" (Nadelhoffer and Tocchetto 2013: I 28).

In addition to the findings of Carey and Paulhus, Nadelhoffer and Tocchetto (2013) have also found some troubling correlations. Using a slightly different scale - The Free Will Inventory (FWI), a 29-item tool for measuring (a) the strength of people's beliefs about free will, determinism, and dualism, and (b) the relationship between these beliefs and related beliefs, such as punishment and responsibility (Nadelhoffer et al. 2014) Nadelhoffer and Tocchetto found, once again, a correlation between free will beliefs and JWB and RWA. They also found a number of correlations between religiosity, conservativism, and political ideology - e.g., RWA was strongly correlated with political conservativism, religiosity, social dominance orientation (SDO), JWB, and economic system justification (ESJ). And here, the ESJ scale measures the tendency to perceive socioeconomic and political arrangements as inherently fair and legitimate - even at the expense of individual or group interests, and the SDO scale measures "the degree of adherence to conservative legitimizing myths that attempt to rationalize the interests of dominant group members" (Nadelhoffer and Tocchetto 20I3: I32).

These findings support the claim that where belief in free will is strongest we tend to see increased punitiveness. In fact, empirical work has confirmed that weakening free will beliefs, either in general or by offering evidence of an individual's diminished decisional capacity, leads to less punitiveness (Pizarro, Uhlmann, and Salovey 2003; Monterosso, Royzman, and Schwartz 2005; Aspinwall et al. 2012; Shariff et al. 2013). These findings also support the claim that a conservative worldview, which is associated with free will belief, is generally correlated with an acceptance of economic inequality and a belief that the world is just and people deserve what they get. One should not be surprised by these correlations since the link between conservative social attitudes and free will belief has long been known (see, e.g., Altemeyer I98I; Weiner 1993; Jost 2006; Baumeister 2008). Robert Altemeyer (I98I), for example, has shown that 
conservatives tend to be more blaming and punitive toward lawbreakers. And John Jost (2006) has found that conservatives and liberals tend to make different trait attributions for lawbreakers - conservatives draw attributions about sinful character, whereas liberals point to situational causes. Hence, the personal responsibility ethic emphasized by conservatives is firmly rooted in (and perhaps even necessitates) belief in free will.

To make clear the potential danger of belief in free will and moral responsibility, let me return to the aforementioned JWB scale. As Nadelhoffer and Tocchetto describe:

The origin of the just world conception can be traced back to the original empirical findings of Lerner and Simmons (1966); namely, that persons have a tendency to blame the victim of misfortunes for their own fate. Based on these empirical findings, Lerner ( 1965 ) formulated the Just World Hypothesis, whereby individuals have a need to believe that they live in a world where people generally get what they deserve. In order to measure the degree to which persons are willing to believe that everyone deserves what happens to them, Lerner (I980) developed the JWB scale. Scores on the scale have been found to correlate with the presence of frail religious beliefs (Sorrentino and Hardy 1974), and internal (as opposed to an external) locus of control, and with the likelihood of derogating innocent victims (Rubin and Peplau 1975). In addition, people who score high on JWB are more likely to trust current institutions and authorities, and to blame the poor and praise the rich for their respective fates (Jost et al. 2003). (Nadelhoffer and Tocchetto 2013: I32)

For sake of time, I will focus the remainder of my comments on JWB. I must unfortunately leave aside the RWA scale - but it should be noted that RWA, just like JWB, is associated with a number of troubling tendencies. ${ }^{7}$

So what's so dangerous about JWB? Well, belief in a just world (which, again, has been shown to be correlated with belief in free will) is a blamethe-victim approach. It promotes the idea that people deserve what they get and people who meet with misfortunate have often brought it on themselves. Adrian Furnham gives a succinct statement of the basic belief in a just world: "The [JWB] asserts that, quite justly, good things tend to happen to good people and bad things to bad people despite the fact that

7 RWA is typically defined in the literature in terms of submission to established and legitimate authorities, sanctioned general aggressiveness toward various persons, and adherence to the generally endorsed social conventions (Nadelhoffer and Tocchetto 20I3: I3 I). Furthermore, "It is also closely related to a large set of ego-justifying tendencies that provide support for social ideologies such as intolerance of ambiguity, dogmatism, terror management, uncertainty avoidance, and need for cognitive closure" (Nadelhoffer and Tocchetto 2013: I3I). 
this is patently not the case" (Furnham 2003: 795). Lerner and Miller also acknowledge the falsehood of this belief, though they point out that it may serve a valuable function in motivating behavior and avoiding a sense of helplessness. This makes the belief difficult to shake:

Since the belief that the world is just serves such an important adaptive function for the individual, people are very reluctant to give up this belief, and they can be greatly troubled if they encounter evidence that suggests that the world is not really just or orderly after all. (Lerner and Miller I978: I03 I)

Because of this, and despite its patent falsehood, belief in a just world continues to exercise a powerful (and often unconscious) influence on our attitudes about free will and moral responsibility (see Waller 2013). Yet despite whatever benefits this false belief may provide, they are bought at a high price. As Waller notes, "ironically, the costs of belief in a just world are paid in fundamental injustice" (Waller 2013: 72).

We can see evidence of JWB in the unfortunate tendency, among both ordinary folk and the legal system, to blame rape victims for their circumstances. When we cannot easily and effectively help innocent victims, our belief in a just world is severely threatened, and the most convenient and common way of preserving that belief is to change the status of the victim from innocent to guilty. As Bruce Waller describes:

The case of rape victims is the most obvious and extensively studied example of this phenomenon. Rape is a brutal, demeaning, and traumaproducing crime; in a just world, no innocent person would be subjected to such a horrific fate. Thus there is a powerful tendency to see rape victims as really not quite so innocent: they dress provocatively; they were "loose" women; they did something to put themselves in that situation (they were careless about where they walked, or they drank too much); they "led him on" or were "asking for it" (thus in some parts of the world, rape victims are subject to death by stoning). Harsh cross-examination of those who claim to be rape victims are notoriously common; those harsh cross-examinations are common because they are often effective; and they are often effective because juries—eager to preserve their belief in a just world—are already inclined to see the victim of this terrible ordeal as other than innocent. (Waller 2013: 73)

This is just one unfortunate example of the pernicious nature of belief in a just world. Other examples include blaming those in poverty for their own circumstances, viewing criminals as deserving what they get, labeling those on welfare as lazy and "mooches," and blaming educational inequity on the parents and children themselves - since, of course, if the 
world is just, then people must have brought these circumstances upon themselves. This blaming of victims (in defense of belief in a just world) has been established by numerous studies, including studies showing that the stronger the belief in a just world the greater the likelihood of blaming victims for their unfortunate fates (Wagstaff I983; Furnham and Gunter 1984; Harper and Manasse 1992; Dalbert and Yamauchi I994; Montada I998).

We all know, however, at least in our more rationally self-reflective moments, that the world is not just and the lottery of life is not always fair. We need to admit that luck plays a big role in what we do and the way we are (see Levy 20 I I; Strawson 2018: ch.4; Caruso 2019b). It's my proposal that we do away with the pernicious belief in free will - and with it the myth of just deserts. If what I have argued here is correct, the concepts of free will and basic desert moral responsibility are intimately connected with a number of other potentially harmful beliefs - e.g., JWB and RWA. It's time that we leave these antiquated notions behind, lose our moral anger, stop blaming the victim, and turn our attention to the difficult task of addressing the causes that lead to criminality, poverty, wealth inequality, and educational inequity (see, e.g., Caruso 2017a).

Let me conclude this section by discussing one last set of studies that reveal the potential benefits of diminished belief in free will. Shariff et al. (2014) hypothesized that, if free will beliefs support attributions of moral responsibility, then reducing these beliefs should make people less retributive in their attitudes about punishment. In a series of four studies they tested this prediction and found reason to be optimistic about free will skepticism. In study I they found that people with weaker free will beliefs endorsed less retributive attitudes regarding punishment of criminals, yet their consequentialist attitudes were unaffected. Study I therefore supports the hypothesis that free will beliefs positively predict punitive attitudes, and in particular retributive attitudes, yet it also suggests that "the motivation to punish in order to benefit society (consequentialist punishment) may remain intact, even while the need for blame and desire for retribution are forgone" (Shariff et al. 20I4: 7). Shariff et al. describe the potential benefits of these findings as follows:

[A] societal shift away from endorsing free will could occur without disrupting the functional role of punishment. Society could fulfill its practical need for law and order, leaving the social benefits of punishment intact while avoiding the unnecessary human suffering and economic costs of punishment often associated with retributivism (Green \& Cohen, 2004; Tonry, 2004). (Shariff et al. 20I4: 7). 
There is no reason to think chaos would ensue if we relinquished our commitment to retributive justice. As this study indicates, other justifications for punishment remain intact and unaffected by diminished belief in free will.

Study 2 found that experimentally diminishing free will belief through anti-free will arguments diminished retributive punishment, suggesting a causal relationship (Shariff et al. 20I4: 6). Studies 3 and 4 further found that exposure to neuroscience implying a mechanistic basis for human action - either reading popular-science articles or taking an introductory neuroscience class in college - similarly produced a reduction in retributivism. Interestingly, studies 3 and 4 made no mention of free will; they let participants draw their own implications from the mechanistic descriptions. These results suggest that shifts in people's philosophical worldview about free will beliefs, "even through simply learning about the brain, can affect people's attitudes about moral responsibility, with potential broad social consequences" (Shariff et al. 2014: 6).

The findings of these studies are promising, at least for the line of argument I've been pushing here, since they show that reducing belief in free will leads people to see others' bad behavior as less morally reprehensible, resulting in less retributive punishment. This is a good thing since it diminishes a harmful kind of moral anger (Pereboom 200I) and an inclination toward excessive punishment. I am also encouraged by these findings that changing attitudes about free will and basic desert moral responsibility - which are probably inevitable as we learn more about neuroscience and the brain ${ }^{8}$ - can help usher in an important evolution in legal thinking away from retributivism and toward practices and policies that are more humane, effective, and just.

\subsection{The Public Health-Quarantine Model}

Let me conclude by addressing one final concern. One of the most frequently voiced criticisms of free will skepticism is that it is unable to

\footnotetext{
${ }^{8}$ As studies 3 and 4 revealed, people naturally become less retributive after having been exposed to neuroscientific and mechanistic descriptions of human behavior. And as Shariff et al. note, "What is clear is that the belief in free will is intertwined with moral, legal, and interpersonal processes. As the mechanistic worldview espoused by many scientists and particularly psychologists, gain attention (e.g., Gazzinga, 20 I I; Nichols, 20 I I; Monterosso and Schwartz, 20 I 2), the impact of these trends good, bad, or both - calls for understanding" (Shariff et al. 2014: 7). This remains true whether or not the mechanistic worldview espoused by these thinkers is correct or a real philosophical threat to free will.
} 
adequately deal with criminal behavior and that responses it would permit as justified are insufficient for acceptable social policy. This concern is fueled by two factors. This first is that one of the most prominent justifications for punishing criminals, retributivism, is incompatible with free will skepticism. The second concern is that alternative justifications that are not ruled out by the skeptical view per se face significant independent moral objections (Pereboom 20I4: I 53). Yet despite these concerns, I maintain that free will skepticism leaves intact other ways to respond to criminal behavior - in particular incapacitation, rehabilitation, and the alteration of relevant social conditions - and that these methods are both morally justifiable and sufficient for good social policy. The position I defend is similar to Derk Pereboom's (200I, 20I4), taking as its starting point his quarantine analogy, but it sets out to develop the quarantine model within a broader justificatory framework drawn from public health ethics. The resulting model - which I call the public healthquarantine model - provides a framework for justifying quarantine and incapacitation that is more humane than retributivism and preferable to other nonretributive alternatives. ${ }^{9}$

The public health-quarantine model is based on an analogy with quarantine and draws on a comparison between treatment of dangerous criminals and treatment of carriers of dangerous diseases. It takes as its starting point Derk Pereboom's famous account (200I, 20I3, 2014). In its simplest form, it can be stated as follows: (I) free will skepticism maintains that criminals are not morally responsible for their actions in the basic desert sense; (2) plainly, many carriers of dangerous diseases are not responsible in this or in any other sense for having contracted these diseases; (3) yet, we generally agree that it is sometimes permissible to quarantine them, and the justification for doing so is the right to selfprotection and the prevention of harm to others; (4) for similar reasons, even if dangerous criminals are not morally responsible for their crimes in the basic desert sense (perhaps because no one is ever in this way morally responsible) it could be as legitimate to preventatively detain them as to quarantine the nonresponsible carrier of a serious communicable disease.

The first thing to note about the theory is that, although one might justify quarantine (in the case of disease) and incapacitation (in the case of dangerous criminals) on purely utilitarian or consequentialist grounds, both Pereboom and I want to resist this strategy. Instead, our view

\footnotetext{
9 For a full defense of the public health-quarantine model, see Caruso (2016, 20I7a, 20I9a),
} Pereboom (200I, 20I4), and Pereboom and Caruso (2018). 
maintains that incapacitation of the seriously dangerous is justified on the ground of the right to self-defense and defense of others. That we have this right has broad appeal, much broader than utilitarianism or consequentialism has. In addition, this makes the view more resilient to a number of objections and provides a more resilient proposal for justifying criminal sanctions than other nonretributive options. One advantage it has, say, over consequentialist deterrence theories is that it has more restrictions placed on it with regard to using people merely as a means (see Pereboom 200I). For instance, as it is illegitimate to treat carriers of a disease more harmfully than is necessary to neutralize the danger they pose, treating those with violent criminal tendencies more harshly than is required to protect society will be illegitimate as well. In fact, in all our writings on the subject, we have always maintained the principle of least infringement, which holds that the least restrictive measures should be taken to protect public health and safety. This ensures that criminal sanctions will be proportionate to the danger posed by an individual, and any sanctions that exceed this upper bound will be unjustified.

Second, the quarantine model places several constraints on the treatment of criminals. First, as less dangerous diseases justify only preventative measures less restrictive than quarantine, so less dangerous criminal tendencies justify only more moderate restraints. We do not, for instance, quarantine people for the common cold even though it has the potential to cause some harm. Rather, we restrict the use of quarantine to a narrowly prescribed set of cases. Analogously, on our model the use of incapacitation should be limited to only those cases where offenders are a serious threat to public safety and no less restrictive measures were available. Secondly, the incapacitation account that results from this analogy demands a degree of concern for the rehabilitation and well-being of the criminal that would alter much of current practice. Just as fairness recommends that we seek to cure the diseased we quarantine, so fairness would counsel that we attempt to rehabilitate the criminals we detain. Rehabilitation and reintegration would therefore replace punishment as the focus of the criminal justice system. Lastly, if criminals cannot be rehabilitated and our safety requires their indefinite confinement, this account provides no justification for making their lives more miserable than would be required to guard against the danger they pose.

In addition to these restrictions on harsh and unnecessary treatment, the public health-quarantine model also advocates for a broader approach to criminal behavior that moves beyond the narrow focus on sanctions. It places the quarantine analogy within the broader justificatory framework 
of public health ethics. Public health ethics not only justifies quarantining carriers of infectious diseases on the grounds that it is necessary to protect public health, it also requires that we take active steps to prevent such outbreaks from occurring in the first place. Quarantine is only needed when the public health system fails in its primary function. Since no system is perfect, quarantine will likely be needed for the foreseeable future, but it should not be the primary means of dealing with public health. The analogous claim holds for incapacitation. Taking a public health approach to criminal behavior would allow us to justify the incapacitation of dangerous criminals when needed, but it would also make prevention a primary function of the criminal justice system. So instead of myopically focusing on punishment, the public health-quarantine model shifts the focus to identifying and addressing the systemic causes of crime, such as poverty, low social economic status, systematic disadvantage, mental illness, homelessness, educational inequity, exposure to abuse and violence, poor environmental health, addiction, and the like (see Caruso 2017a).

In my recent Public Health and Safety: The Social Determinants of Health and Criminal Behavior (Caruso 2017a), I argue that the social determinants of health $(\mathrm{SDH})$ and the social determinants of criminal behavior (SDCB) are broadly similar, and that we should adopt a broad public health approach for identifying and taking action on these shared social determinants. I focus on how social inequities and systemic injustices affect health outcomes and criminal behavior, how poverty affects brain development, how offenders often have preexisting medical conditions (especially mental health issues), how homelessness and education affect health and safety outcomes, how environmental health is important to both public health and safety, how involvement in the criminal justice system itself can lead to or worsen health and cognitive problems, and how a public health approach can be successfully applied within the criminal justice system. I argue that, just as it is important to identify and take action on the SDH if we want to improve health outcomes, it is equally important to identify and address the SDCB. And I conclude by offering eight broad public policy proposals for implementing a public health approach aimed at addressing the SDH and SDCB (see Caruso 2017a for details).

Furthermore, the public health framework I adopt sees social justice as a foundational cornerstone to public health and safety. In public health ethics, a failure on the part of public health institutions to ensure the social conditions necessary to achieve a sufficient level of health is 
considered a grave injustice. An important task of public health ethics, then, is to identify which inequalities in health are the most egregious and thus which should be given the highest priority in public health policy and practice. The public health approach to criminal behavior likewise maintains that a core moral function of the criminal justice system is to identify and remedy social and economic inequalities responsible for crime. Just as public health is negatively affected by poverty, racism, and systematic inequality, so too is public safety. This broader approach to criminal justice therefore places issues of social justice at the forefront. It sees racism, sexism, poverty, and systemic disadvantage as serious threats to public safety and it prioritizes the reduction of such inequalities.

While there are different ways of understanding social justice and different philosophical accounts of what a theory of justice aims to achieve, I favor a capability approach, according to which the development of capabilities - what each individual is able to do or be - is essential to human well-being (e.g., Sen 1985, I999; Power and Faden 2006; Nussbaum 20II). For capability theorists, human well-being is the proper end of a theory of justice. And on the particular capability approach I favor, social justice is grounded in six key features of human well-being: health, reasoning, self-determination, attachment, personal security, and respect (see Powers and Faden 2006; Caruso 2017a). ${ }^{10}$ Following Powers and Faden (2006), I maintain that each of these six dimensions is an essential feature of well-being such that "a life substantially lacking in any one is a life seriously deficient in what it is reasonable for anyone to want, whatever else they want" (Powers and Faden 2006: 8). The job of justice is therefore to achieve a sufficiency of these six essential dimensions of human wellbeing, since each is a separate indicator of a decent life.

The key idea of capability approaches is that social arrangements should aim to expand people's capabilities - their freedom to promote or achieve functionings that are important to them. Functionings are defined as the valuable activities and states that make up human well-being, such as having a healthy body, being safe, or having a job. While they are related to goods and income, they are instead described in terms of what a person is able to do or be as a result. For example, when a person's need for food (a commodity) is met, that person enjoys the functioning of being well nourished. Examples of functionings include being mobile, being healthy, being adequately nourished, and being educated. The genuine opportunity

Io Note that this is a pared-down list from the ones offered by Martha Nussbaum and other capability theorists (see Nussbaum 20I I). 
to achieve a particular functioning is called a capability. Capabilities are "the alternative combination of functionings that are feasible for [a person] to achieve" - they are "the substantive freedom" a person has "to lead the kind of life he or she has reason to value" (Sen 1999: 87).

As Tabandeh, Gardoni, and Murphy describe:

Genuine opportunities and actual achievements are influenced by what individuals have and what they can do with what they have. What they can do with what they have is a function of the structure of social, legal, economic, and political institutions and of the characteristics of the builtenvironment (i.e., infrastructure). For example, consider the functioning of being mobile. The number of times an individual travels per week can be an indicator of mobility achievement. When explaining a given individual's achievement or lack of achievement, a capability approach takes into consideration the conditions that must be in place for an individual to be mobile. For instance, the possession of certain resources, like a bike, may influence mobility. However, possessing a bike may not be sufficient to guarantee mobility. If the individual has physical disabilities, then the bike will be of no help to travel. Similarly, if there are no paved roads or if societal culture imposes a norm that women are not allowed to ride a bike, then it will become difficult or even impossible to travel by means of a bike. As this example makes clear, different factors will influence the number of times the individual travels. (Tabandeh et al. 2018)

Thinking in terms of capabilities raises a wider range of issues than simply looking at the amount of resources or commodities people have, because people have different needs. In the example given earlier, just providing bicycles to people will not be enough to increase the functioning of being mobile if you are disabled or prohibited from riding because of sexist social norms. A capabilities approach to social justice therefore requires that we consider and address a larger set of social issues.

Bringing everything together, my public health-quarantine model characterizes the moral foundation of public health as social justice, not just the advancement of good health outcomes. That is, while promoting social goods (like health) is one area of concern, public health ethics as I conceive it is embedded within a broader commitment to secure a sufficient level of health and safety for all and to narrow unjust inequalities (see Powers and Faden 2006). More specifically, I see the capability approach to social justice as the proper moral foundation of public health ethics. This means that the broader commitment of public health should be the achievement of those capabilities needed to secure a sufficient level of human wellbeing - including, but not limited to, health, reasoning, self-determination, attachment, personal security, and respect. By placing social justice at the 
foundation of the public health approach, the realms of criminal justice and social justice are brought closer together. I see this as a virtue of the theory since it is hard to see how we can adequately deal with criminal justice without simultaneously addressing issues of social justice. Retributivists tend to disagree since they approach criminal justice as an issue of individual responsibility and desert, not as an issue of prevention and public safety. I believe it is a mistake to hold that the criteria of individual accountability can be settled apart from considerations of social justice and the SDCB. Making social justice foundational, as my public healthquarantine model does, places on us a collective responsibility - which is forward looking and perfectly consistent with free will skepticism - to redress unjust inequalities and to advance collective aims and priorities such as public health and safety. The capability approach and the public health approach therefore fit nicely together. Both maintain that poor health and safety are often the byproducts of social inequities, and both attempt to identify and address these social inequities in order to achieve a sufficient level of health and safety.

Summarizing the public health-quarantine model, then, the core idea is that the right to self-defense and defense of others justifies incapacitating the criminally dangerous with the minimum harm required for adequate protection. The resulting account would not justify the sort of criminal punishment whose legitimacy is most dubious, such as death or confinement in the most common kinds of prisons in our society. The model also specifies attention to the well-being of criminals, which would change much of current policy. Furthermore, the public health component of the theory prioritizes prevention and social justice and aims at identifying and taking action on the SDH and criminal behavior. This combined approach to dealing with criminal behavior, I maintain, is sufficient for dealing with dangerous criminals, leads to a more humane and effective social policy, and is actually preferable to the harsh and often excessive forms of punishment that typically come with retributivism. ${ }^{\text {I }}$

\subsection{Conclusion}

I have here examined some of the practical implications of free will skepticism and argued that we should be optimistic about the prospects of life without free will. Defenders of free will, along with illusionists like

II For responses to various objections to the model, see Pereboom and Caruso (2018), Caruso (2019a), and Pereboom (2013C, 20I7). 
Saul Smilansky (2000, 2013; Ch.2 [this volume]), maintain that belief in free will is essential for the proper functioning of society, morality, and the law. Optimistic skeptics and disillusionists, on the other hand, disagree. Making the case for optimism, I argued that belief in free will and basic desert moral responsibility, rather than being a good thing, actually has a dark side and that we would be better off without it. In Section 3.I, I briefly examined two common concerns people have with relinquishing the belief in free will - that it will lead to an increase in antisocial behavior and that it will lead to cruel and inhumane forms of punishment. I argued that these concern are misguided and overblown. In Section 3.2, I then discussed recent empirical findings in moral and political psychology that reveal interesting, and potentially troubling, correlations between people's free will beliefs and their other moral, religious, and political views - i.e., belief in free will is associated with increased belief in a just world, RWA, religiosity, punitiveness, and moralistic standards for judging self and other. We found that these associations, especially belief in a just world and the punitive desire to blame and punish others, often lead to negative and counterproductive practices, policies, and tendencies. I concluded in Section 3.3 by addressing one final concern regarding free will skepticism: whether it can successfully deal with criminal behavior. I argued that the public health-quarantine model is not only consistent with free will skepticism, it offers an ethically defensible and practically workable alternative, one that is more holistic and humane than retributive punishment. While these considerations do not prove belief in free will is mistaken, they do indicate that the putative pragmatic benefits of believing in free will and basic desert moral responsibility are bogus.

\section{REFERENCES}

Alicke, M. D. (1994). Evidential and extra-evidential evaluations of social conduct. Journal of Social Behavior and Personality, 9, 591-6I 5.

Alicke, M. D. (2008). Blaming badly. Journal of Cognition and Culture, 8, I79-I 86 .

Alicke, M. D., J. Buckingham, E. Zell, and T. Davis. (2008). Culpable control and counterfactual reasoning in the psychology of blame. Personality and Social Psychology Bulletin, 34, I37I-I38I.

Altemeyer, R. A. (198I). Right-Wing Authoritarianism. Manitoba: University of Manitoba Press.

(1996). The Authoritarian Specter. Cambridge, MA: Harvard University Press. (2003). Why do religious fundamentalists tend to be prejudiced? International Journal for the Psychology of Religion, 13,17-28. 
Aspinwall, L. G., T. R Brown, and J. Tabery. (20I2). The double-edged sword: Does biomechanism increase or decrease judges' sentencing of psychopaths? Science, 337, 846-849.

Barna Research Group Survey. (1999). U.S. divorce rates for various faith groups, age groups, and geographic areas. Available at www.religioustolerance .org/chr_dira.htm (last accessed 22 June 2009).

(2007). Atheists and agnostics take aim at Christians. Available at www .barna.org/barna-update/article/ I 2 -faithspirituality/I02-atheists-and-agnosticstake-aim-at-christians (last accessed 22 June 2009).

Baumeister, R. F. (2008). Free will, consciousness, and cultural animals. In J. Bear, J. Kaufman, and R. Baumeister, eds., Are We Free? Psychology and Free Will. New York: Oxford University Press, pp. 65-85.

Baumeister, R. F., E. J. Masicampo, and C. N. DeWall. (2009). Prosocial benefits of feeling free: Disbelief in free will increases aggression and reduces helpfulness. Personality and Social Psychology Bulletin, 35(2), 260-268.

Berg, K. S., and N. Vidmar. (1975). Authoritarianism and recall of evidence about criminal behavior. Journal of Research in Personality, 9, I47-I 57.

Brinkerhoff, M., E. Grandin, and E. Lupri. (1992). Religious involvement and spousal violence: The Canadian case. Journal for the Scientific Study of Religion, 3I, I 5-3 I.

Carey, J. M., and D. L. Paulhus. (2013). Worldview implication of believing in free will and/or determinism: Politics, morality, and punitiveness. Journal of Personality, 8I(2), I 30-I4I.

Carey, B., and M. Roston. (2015). Three popular psychology studies that didn't hold up. The New York Times. Retrieved from: www.nytimes.com/inter active/201 5/08/28/science/psychology-studies-redid.html.

Caruso, G. D. (2012). Free Will and Consciousness: A Determinist Account of the Illusion of Free Will. Lanham, MD: Lexington Books.

Caruso, G. D. (2016). Free will skepticism and criminal behavior: A public health-quarantine model. Southwest Philosophy Review, 32(I), $25-48$.

(2017a). Public Health and Safety: The Social Determinants of Health and Criminal Behavior. London: ResearchLinks Books.

(20I7b). Free will skepticism and the questions of creativity: Creativity, desert, and self-creation. Ergo, 3(23), 591-607.

(2018). Skepticism about moral responsibility. Stanford Encyclopedia of Philosophy. Available at: https://plato.stanford.edu/entries/skepticism-moralresponsibility/

Caruso, G. D. (2019a). The public health-quarantine model. In D. Nelkin and D. Pereboom, eds., Oxford Handbook on Moral Responsibility. New York: Oxford University Press.

(2019b). A defense of the luck pincer: Why luck (still) undermines free will and moral responsibility. Journal of Information Ethics, April/May Issue.

Caruso, G. D., and S. Morris. (2017). Compatibilism and retributivist desert moral responsibility: On what is of central philosophical and practical importance. Erkenntnis, 82, 837-855. 
Clark, T. (2013). Experience and autonomy: Why consciousness does and doesn't matter. In G. D. Caruso, ed., Exploring the Illusion of Free Will and Moral Responsibility. Lanham, MD: Lexington Books, pp. 239-254.

Clark, C. J., P. H. Ditto, A. F. Shariff, et al. (20I4). Free to punish: A motivated account of free will belief. Attitudes of Social Cognition, I06(4), 50 I-5I3.

Corrado, M. L. (2013). Why do we resist hard incompatibilism? Thoughts on freedom and punishment. In T. Nadelhoffer, ed., The future of punishment. New York: Oxford University Press, pp. 79-106.

Crick, F. (I994). The Astonishing Hypothesis. New York: Scriber.

Crone, D., and N. Levy. (2018). Are free will believers nicer people (Four studies suggest not). Open Science Framework, January io. Retrieved from: osf.io/ m9sre

Dalbert, C., and L. Yamauchi. (I994). Belief in a just world and attitudes toward immigrants and foreign workers: A cultural comparison between Hawaii and Germany. Journal of Applied Social Psychology, 24, I6 I 2-1626.

Death Penalty Information Center. (2008). Regional murder rates, 200I-2007. Available at: www.death-penaltyinfo.org/murder-rates-I996-2007 (last accessed 22 June 2009).

Earp, B. D., J. A. C. Everett, T. Nadelhoffer, et al. (2018). Determined to be humble? Exploring the relationship between belief in free will and humility. PsyArXiv. Available at: https://psyarxiv.com/3bxra

Efran, M. G. (I974). The effect of physical appearance on the judgment of guilt, interpersonal attraction, and severity of recommended punishment in a simulated jury task. Journal of Research and Personality, 8, 45-54.

Ellison, C., J. Burr and P. McCall. (2003). The enduring puzzle of southern homicide. Homicide Studies, 7, 326-352.

Epley, N., and D. Dunning. (2000). Feeling "holier than thou": Are self-serving assessments produced by errors in self or social prediction? Journal of Personality and Social Psychology, 79, 86I-875.

Everett, J. A. C., J. B. Luguri, C. J. Clark, et al. (2018). Free to blame? Political differences in free will belief are driven by differences in moralization. Available at: https://psyarxiv.com/nx9rj/

Fajnzylber, O., D. Lederman, and N. Loatza. (2002). Inequality and violent crime. Journal of Law and Economics, XLV, I-4O.

Fox, J. and J. Levin. (2000). The Will to Kill. Boston, MA: Allyn and Bacon.

Furnham, A. (2003). Belief in a just world: Research progress over the past decade. Personality and Individual Differences, 34, 795-8I7.

Furnham, A., and B. Gunter. (I984). Just world beliefs and attitudes towards the poor. British Journal of Social Psychology, I 5, 265-269.

Gazzinga, M. (20 I I). Who's in Charge? Free Will and the Science of the Brain. New York: Harper.

Greene, J. D., and J. Cohen. (2004). For the law, neuroscience changes nothing, and everything. Philosophical Transactions of the Royal Society of London, B 359, I775-I785. DOI: Io. I098/rstb.2004.I 546 (accessed 26 October 20I2). 
Hardcastle, V. (2018). The neuroscience of criminality and our sense of justice: An analysis of recent appellate decisions in criminal cases. In G. D. Caruso and O. Flanagan, eds., Neuroexistentialism: Meaning, Morals, and Purpose in the Age of Neuroscience. New York: Oxford University Press, pp. 3 I I-332.

Harper, D., and P. Manasse. (I992). The just world and the third world: British explanations for poverty abroad. Journal of Social Psychology, 132, $783-785$.

Jensen, G. F. (2006). Religious cosmologies and homicide rates among nations. The Journal of Religion and Society, 8, I-I 3.

Jost, J. T. (2006). The end of the end of ideology. American Psychologist, 6r, $65 \mathrm{I}-670$.

Jost, J. T., S. Blount, J. Pfeffer, and G. Hunyady. (2003). Fair market ideology: Its cognitive-motivational underpinnings. Research in Organizational Behavior, 25, 53-9I.

Lagnado, D. A., and S. Channon. (2008). Judgments of cause and blame: The effects of intentionality and foreseeability. Cognition, I08, 754-770.

Lerner, M. J. (1965). Evaluation of performance as a function of performer's reward and attractiveness. Journal of Personality and Social Psychology, I, 355-360.

(1980). The Belief in a Just World: A Fundamental Delusion. New York: Plenum Press.

Lerner, M. J., and D. T. Miller. (1978). Just world research and the attribution process: Looking back and ahead. Psychological Bulletin, 85, I030-105 I.

Lerner, M. J., D. T. Miller, and J. G. Holmes. (1976). Deserving and the emergence of forms of justice. In L. Berkowitz and E. Walster, eds., Advances in Experimental Social Psychology, pp. I 34-162.

Lerner, M. J., and C. H. Simmons. (I 966). Observer's reaction to the "innocent victim": Compassion or rejection? Journal of Personality and Social Psychology, 4, 203-2IO.

Levy, N. (20 I I). Hard Luck: How Luck Undermines Free Will and Moral Responsibility. Oxford: Oxford University Press.

Levy, N. (2012). Skepticism and sanctions: The benefit of rejecting moral responsibility. Law and Philosophy, 3I(5), 477-493.

Lewis, C. S. (I97I). The humanitarian theory of punishment. In his, God in the Dock: Essays on Theology and Ethics. Cambridge: William B. Eerdmans Publishing, pp. 287-294.

MacKenzie, M. J., K. D. Vohs, and B. F. Baumeister. (20I4). You didn't have to do that: Belief in free will promotes gratitude. Personality and Social Psychology Bulletin, DOI: Io.I I77/o I 46I672 I 4549322.

Milam, P-E. (2016). Reactive attitudes and personal relationships. Canadian Journal of Philosophy, 46(I), I $02-\mathrm{I} 22$.

Montada, L. (I998). Belief in a just world: A hybrid of justice motive and selfinterest. In L. M. and M. Lerner, eds., Responses to Victimizations and Belief in the Just World. New York: Plenum, pp. 217-245. 
Monterosso, J., Royzman, E. B., and B. Schwartz. (2005). Explaining away responsibility: Effects of scientific explanation on perceived culpability. Ethics and Behavior, I5, I39-I 58.

(2012). Did your brain make you do it? New York Times. July 27, 20 I 4.

Morris, H. (I968). Persons and punishment. The Monist, 52, 475-50I.

Nadelhoffer, T. 2006. Bad acts, blameworthy agents, and intentional actions: Some problems for juror impartiality. Philosophical Explorations, 9(2), 203-2 I9.

20 I I. The threat of shrinking agency and free will disillusionism. In L. Nadel and W. Sinnott-Armstrong, eds., Conscious Will and Responsibility: A Tribute to Benjamin Libet. New York: Oxford University Press, pp.I73-I88.

Nadelhoffer, T., and D. Goya Tocchetto. (2013). The potential dark side of believing in free will (and related concepts): Some preliminary findings. In G. D. Caruso, ed., Exploring the Illusion of Free Will and Moral Responsibility. Lanham, MD: Lexington Books, pp. I 2 I-I 40.

Nadelhoffer, T., E. Nahmias, L. Ross, J. Shepard, and C. Sripada. (2014). The free will inventory: Measuring beliefs about agency and responsibility. Consciousness and Cognition, 25, 27-4I.

Nadelhoffer, T., and J. C. Wright. (2018). Humility, free will beliefs, and existential angst: How we got from a preliminary investigation to a cautionary tale. In G. D. Caruso and O. Flanagan, eds., Neuroexistentialism: Meaning, Morals, and Purpose in the Age of Neuroscience. New York: Oxford University Press, pp. 269-297.

Neimeth, C., and R. H. Sosis. (I973). A simulated jury: Characteristics of the defendant and the jurors. Journal of Social Psychology, 90, 22 I-229.

Nichols, S. (20 I I). Is free will an illusion? Scientific American Mind, 22, I8-I9.

Nussbaum, M. (20I I). Creating capabilities: The human development approach. Cambridge, MA: Harvard University Press.

Oldenquist, A. (I 988). An explanation of retribution. Journal of Philosophy, 85, $464-478$.

Open Science Collaboration. (2015). Estimating the reproducibility of psychological science. Science, 349(625I), aac47 I6: DOI: Io. I I 26/science .aac47 I 6.

Paul, G. S. (2005). Is the Baylor religion study reliable?: An analysis from the council for secular humanism. Available at: http://gai.org/center_for_ inquiry/notice-description.tcl?newsletter_id= I I 076763 .

Paulhus, D. L., and J. M. Carey. (20II). The FAD-Plus: Measuring lay beliefs regarding free will and related constructs. Journal of Personality Assessment, 93, 96-I04.

Pereboom, D. (2001). Living Without Free Will. New York: Cambridge University Press.

Pereboom, D. (2013a). Optimistic skepticism about free will. In P. Russell and O. Deery, eds., The Philosophy of Free Will: Selected Contemporary Readings. New York: Oxford University Press, pp. 42 I-449.

(201 3b). Skepticism about free will. In G. D. Caruso, ed., Exploring the Illusion of Free Will and Moral Responsibility. Lanham, MD: Lexington Books, pp. 19-40. 
(2013c). Free will skepticism and criminal punishment. In T. Nadelhoffer, ed., The Future of Punishment. New York: Oxford University Press, pp. 49-78.

Pereboom, D. (20I4). Free Will, Agency, and Meaning in Life. Oxford: Oxford University Press.

Pereboom. D. (20I7). A defense of free will skepticism: Replies to commentaries by Victor Tadros, Saul Smilansky, Michael McKenna, and Alfred R. Mele on Free Will, Agency, and Meaning in Life. Criminal Law and Philosophy, II (3), 6I7-636.

Pereboom, D., and G. D. Caruso. (2018). Hard-incompatibilist existentialism: Neuroscience, punishment, and meaning in life. In G. D. Caruso and O. Flanagan, ed., Neuroexistentialism: Meaning, Morals, and Purpose in the Age of Neuroscience. New York: Oxford University Press, pp. 193-222.

Pizarro, D., E. Ulhmann, and P. Salovey. (2003). Asymmetry in judgments of moral blame and praise: The of perceived metadesires. Psychological Science, I4, 267-272.

Powers, M. and R. Faden (2006). Social Justice: The Moral Foundations of Public Health and Health Policy. New York: Oxford University Press.

Rubin, Z., and L. A. Peplau. (1975). Who believes in a just world? Journal of Social Issues, 31, 65-89.

Schlenker, B. R. (I980). Impression Management: The Self-Concept, Social Identity, and Interpersonal Relations. Monterey, CA: Brooks/Cole.

Sen, A. (1985). Commodities and Capabilities. Amsterdam: North-Holland.

(1999). Development as Freedom. New York: Oxford University Press.

Shariff, A. F., J. D. Greene, J. C. Karremans, et al. (20I4). Free will and punishment: A mechanistic view of human nature reduces retribution. Psychological Science, June io, I-8.

Sie, M. (2013). Free will, an illusion? An answer from a pragmatic sentimentalist point of view. In G. D. Caruso, ed., Exploring the Illusion of Free Will and Moral Responsibility. Lanham, MD: Lexington Books, pp. 273-290.

Smilansky, S. (200o). Free Will and Illusion. New York: Oxford University Press. Smilansky, S. (2013). Free will as a case of "crazy ethics." In G. D. Caruso, ed., Exploring the Illusion of Free Will and Moral Responsibility. Lanham, MD: Lexington Books, pp. I03-I20.

Snyder, C. R., R. L. Higgins, and R. J. Stuckey. (1983). Excuses: Masquerades in Search of Grace. Clinton Corners, NY: Eliot Werner Publications.

Sorrentino, R. M., and J. Hardy. (I974). Religiousness and derogation of an innocent victim. Journal of Personality, 42, 372-382.

Sosis, R. H. (I974). Internal-external control and the perception of responsibility of another for an accident. Journal of Personality and Social Psychology, 30, 393-399.

Stillman, T. F., and R. F. Baumeister. (2010). Guilt, free, and wise: Belief in free will facilitates Learning from self-conscious emotions. Journal of Experimental Social Psychology, 46, 95 I-960.

Stillman, T. F., R. F. Baumeister, K. D. Vohs, N. M. Lambert, F. D. Fincham, and L. E. Brewer. (2010). Personal philosophy and personnel achievement: 
Belief in free will predicts better job performance. Social Psychological and Personal Science, I(I), 43-50.

Strawson, G. (I986). Freedom and Belief. Oxford: Oxford University Press.

(I994). The impossibility of moral responsibility. Philosophical Studies, 75(I), $5-24$.

(2010). Freedom and Belief, Revised edition. Oxford: Oxford University Press. (2018). Things That Bother Me: Death, Freedom, the Self, etc. New York: New York Review Book.

Tabandeh, A. P., P. Gardoni, and C. Murphy. (2018). A reliability-based capability approach. Risk Analysis, 38(2), 4IO-424.

Tonry, M. (2004). Thinking About Crime: Sense and Sensibility in American Penal Culture. New York: Oxford University Press.

Vilhauer, B. (2010). Persons, punishment, and free will skepticism. Philosophical Studies, DOI: Io.1007/si I098-0I I-9752-z.

Vilhauer, B. (2013). The people problem. In G. D. Caruso, ed., Exploring the Illusion of Free Will and Moral Responsibility. Lanham, MD: Lexington Books, pp. I4I-I60.

Vohs, K. D., and J. W. Schooler. (2008). The value of believing in free will: Encouraging a belief in determinism increases cheating. Psychological Science, I9, 49-54.

Wagstaff, G. F. (1983). Correlates of the just world in Britain. Journal of Social Psychology, I2I, I45-I 46.

Waller, B. (20 I I). Against Moral Responsibility. Cambridge, MA: MIT Press.

Waller, B. (2013). The stubborn illusion of moral responsibility. In G. D. Caruso, ed., Exploring the Illusion of Free Will and Moral Responsibility. Lanham, MD: Lexington Books, pp. 65-86.

Waller, B. (2014a). The culture of moral responsibility. Southwest Philosophical View, 30(I), 3-I7.

(20I4b). The Stubborn System of Moral Responsibility. Cambridge, MA: MIT Press.

(2015). Restorative Free Will: Back to the Biological Base. Lanham, MA: Lexington Books.

Weiner, B. (I993). On sin and sickness: A theory of perceived responsibility and social motivation. American Psychologist, 48, 957-965.

Zuckerman, P. (2009). Atheism, secularity, and well-being: How the findings of social science counter negative stereotypes and assumptions. Sociology Compass, 3/6, 949-97I.

Zwaan, R. (2013). The value of believing in free will: a replication attempt. March I 8, 20I3. Retrieved from: https://rolfzwaan.blogspot.com/2013/o3/ the-value-of-believing-in-free-will.html. 